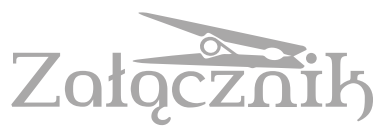

DOI 10.21697/zk.2020.7.01

\title{
GROZA NIEBA. GIAMBATTISTA VICO I HERMANN USENER O LĘKOWYCH ŹRÓDŁACH KULTURY
}

Robert PAWLIK

Wydział Nauk Humanistycznych UKSW

Department of Humanities,

Cardinal Stefan Wyszyński University in Warsaw

r.pawlik@uksw.edu.pl

ORCID: 0000-0002-0728-4347

Wszystko bowiem czynimy po to, aby nie cierpieć $i$ się nie bać.

Epikur

\section{WSTĘP}

Giambattista Vico w swym dziele Principi di una Scienza Nuova d'intorno alla natura delle Nazioni (1725) stworzył projekt nauki badającej świat społeczny człowieka ${ }^{1}$. Dociekanie zasad kształtujących i rządzących wspólnotowym życiem ludzi projektował jako „nową naukę”, gdyż, w odróżnieniu od dynamicznie rozwijających się w XVII i XVIII stuleciu studiów nad światem przyrody ${ }^{2}$, systematyczny filozoficzny namysł nad naturą świata kultury nie był jeszcze rozwinięty. Za bazę źródłową scienza nuova neapolitański filozof uznał nazwy, metafory, legendy i mity oraz dzieła poetyckie, historyczne i prawne, które odpowiednio zinterpretowane, stanowią wrota do

1 Tłumaczenie polskie: G. Vico, Nauka nowa, tłum. J. Jakubowicz, oprac. i wstęp S. Krzemień-Ojak, Warszawa 1966. Odniesienia do cytatów z tego wydania lokuję bezpośrednio w tekście, podając numer paragrafu.

2 „Filozofowie z taką uwagą badali świat natury, który znać może tylko Bóg, jego stwórca, zaniedbując natomiast badanie świata narodów, stworzonego przez ludzi, a więc dostępnego ludzkiej wiedzy" (\$. 331). Symbolem badań świata natury była dla Vica praca Isaaca Newtona Philosophiae Naturalis Principia Mathematica, Londini 1687 (wyd. pol. Matematyczne zasady filozofii przyrody, tłum., wstęp i komentarz J. Wawrzycki, Kraków - Rzeszów 2011), do której czyni aluzję tytuł pracy włoskiego filozofa. 
najdawniejszej przeszłości człowieka, ujawniając pierwotne doświadczenia ludzi oraz ich mentalność.

W ten sposób do rangi podstawowego materiału empirycznego Vico wyniósł to, czemu kartezjańska tradycja filozoficzna odmawiała epistemologicznej wartości. W tym, w czym Kartezjusz widział co najwyżej „budujące opowieści”’, neapolitański filozof dostrzegł wytwory zbiorowej kreatywności człowieka, poddające się badaniu dlatego właśnie, że przez samych ludzi zostały stworzone. Podstawą nowej nauki, której Vico nadał miano „filologii” (\$7), było założenie, że można zrozumieć to, co samemu powołało się do istnienia. Filologia miała badać początki religii, języka oraz instytucji polityczno-prawnych ${ }^{4}$.

Wyróżnikiem podejścia neapolitańskiego myśliciela była specyficzna rola, jaką przypisał Opatrzności w powstaniu świata społecznego. Przeciw tezie, że do rozwoju cywilizacji doprowadziły przypadkowe instynkty i namiętności, Vico wysuwał decydujące znaczenie boskiego zamysłu, twierdząc, że ustanawiając życie zbiorowe, Bóg „posłużył się” ludzkimi „instynktownymi potrzebami” (\$2). W polemice z epikurejską doktryną ślepego trafu dowodził, że w historii urzeczywistnia się boski plan. W przeciwieństwie do prehistorii lukrecjańskiej, głoszącej, że w powstaniu cywilizacji bogowie nie odegrali żadnej roli, Vico twierdził, że rola ta była kluczowa. Ów jawnie anty-epikurejski teoremat łączył jednak z par excellence epikurejskim przekonaniem, że kosmos instytucji społecznych wyłonił się z chaosu instynktów i namiętności quasi-animalnych istot pierwotnych oraz że głównym motorem powstania religii, języka, rodziny i polityki był strach. W rezultacie dawał do zrozumienia, że „świat społeczny [mondo civile] został z całą pewnością stworzony przez ludzi” (\$331), co równa się tezie, że ludzie stworzyli samych siebie.

3 Kartezjusz, Rozprawa o metodzie właściwego kierowania rozumem i poszukiwania prawdy w naukach, tłum. i oprac. W. Wojciechowska, Warszawa 1970, s. 6-9.

4 „Filologia jest nauką o tym wszystkim, co zależy od ludzkiej woli, i obejmuje dzieje języków i obyczajów, sprawy wojny i pokoju między narodami” (\$7); „Tak oto Nauka nasza staje się zarazem historią idei, obyczajów oraz wydarzeń rodzaju ludzkiego" (\$368). 
W niniejszej szkicu przeanalizuję jeden aspekt Vikiańskiego ujęcia prehistorii: koncepcję fobicznych źródeł cywilizacji. Vico wyprowadził instytucje życia społecznego z lękowej reakcji na grozę natury, której najbardziej uderzającym przykładem jest pradawny strach człowieka przed piorunem. W drugiej części omówię późniejsze o blisko dwa stulecia studium Hermanna Usenera pt. Keraunos (1905), gdzie niemiecki filolog, intepretując grecko-rzymskie świadectwa kultu Pioruna, nakreślił koncepcję powstawania i ewolucji pojęć religijnych. Rozprawa Usenera nie tylko wspiera Vikiańską hipotezę genezy cywilizacji, ale pozwala też na sformułowanie ogólniejszego wniosku na temat pewnej tradycji refleksji nad kulturą, którą można by nazwać epikurejską.

\section{NA POCZĄTKU BYŁ STRACH}

W swej charakterystyce przejścia od przedludzkich początków do życia społecznego czy obywatelskiego (mondo civile) Vico należał do ostatnich filozofów XVIII stulecia, którzy przyjmowali biblijną chronologię, zakładając że do potopu wszystko przebiegało tak, jak oznajmia Pismo, a pierwszy człowiek stworzony został na obraz i podobieństwo Boże, aby żyć w rajskiej harmonii. Jednak po potopie, który zniszczył pierwotną cywilizację, dzieje zbawienia i historia świecka radykalnie się rozwidliły ${ }^{5}$. Posłuszni swemu Bogu Hebrajczycy pozostali na ścieżce cywilizacji, zachowując instytucje prawne i społeczne, które otrzymali bezpośrednio od Boga, natomiast potomkowie Chama, Jafeta i Sema, porzuciwszy religię żydowską wraz z jej prawami, zdegenerowali się do poziomu półzwierzęcych olbrzymów (bestioni) $^{6}$. Zdeformowani nawet fizycznie, prowadzili życie nomadów błąkających się po lasach, kierując się wyłącznie egoistycznymi potrzebami

5 „Te dwa twierdzenia jasno ukazują, iż pierwotnie cały rodzaj ludzki dzielił się na dwie kategorie: olbrzymów i ludzi normalnego wzrostu, czyli pogan i Hebrajczyków. Przyczyną tej różnicy może być jedynie zwierzęce wychowanie jednych oraz ludzkie drugich. Wynika stąd, że Hebrajczycy byli innego pochodzenia aniżeli wszyscy poganie" (\$172).

6 „W ciągu bardzo długiego czasu bezbożni potomkowie trzech synów Noego doszli do stanu zwierzęcego. Błąkając się niby dzikie zwierzęta, rozproszyli się oni po wielkiej puszczy ziemskiej, a wyniku zwierzęcego wychowania pojawili się wśród nich olbrzymi” (\$195). 
i żądzami. W nich właśnie Vico widział protoplastów narodów pogańskich? Podstawowe pytanie brzmiało: w jaki sposób owe bezrozumne i nieokiełznane istoty, nieznające życia zbiorowego (\$374), przeobraziły się w ludzi prowadzących żywot w ramach zorganizowanych społeczeństw? Jak doszło do przezwyciężenia zwierzęcego sposobu życia i uregulowania stosunków społecznych?

Vico wyjaśniał, że proces dźwigania się ze stanu dzikości rozpoczął się dwieście lat po potopie, wraz z pierwszą burzą. W jednym z najlepiej znanych fragmentów Nauki nowej tłumaczył:

Tacy prawdopodobnie byli pierwsi twórcy cywilizacji pogańskiej, kiedy niebo nareszcie rozbłysło i zagrzmiało wśród straszliwych huków i błyskawic, które musiały nastąpić przy gwałtownym pierwszym wstrząsie powietrza. [...] Wówczas to nieliczni olbrzymi, bez wątpienia najsilniejsi z tych, którzy rozpierzchli się po gajach rosnących na szczytach gór, mając tam podobnie jak zwierzęta swoje kryjówki, przerażeni i osłupiali wobec nieznanego zjawiska, spojrzeli w górę i dostrzegli niebo (\$377).

W narracji Vica „sceną pierwotną”, inicjującą proces cywilizacji, jest traumatyczne doświadczenie pierwszej burzy. Przyczyną, która skierowała na poły animalnych olbrzymów na ścieżki cywilizacji, był szok: przeżycie obezwładniającej trwogi. Oślepiające błyskawice i ogłuszający huk piorunów wprawił bestioni w stan śmiertelnego przerażenia, w którym zwrócili się ku źródłu lęku - niebu, w którym - mocą swej wybujałej wyobraźni - ujrzeli żywe, cielesne jestestwo, za pomocą gromów próbujące im coś zakomunikować. „Wyobrazili sobie niebo jako ogromne żywe ciało i dlatego nazwali je Jowiszem” (\$ 377).

W tej twórczej odpowiedzi na stan głębokiej trwogi Vico upatrywał potęgi wyobraźni charakteryzującej prymitywnych ludzi. Przy braku wiedzy na temat przyczyn zjawisk to ona pozwoliła im radzić sobie z paraliżującym przerażeniem. Pierwsi ludzie zareagowali na źródło lęku w jedyny dostępny sobie sposób: projekcją samych siebie, pojmując grzmiący firmament jako

7 „[...] rasy Chama, Jafeta a także Sema - odrzuciwszy religię swego ojca Noego, jedyną, która w ówczesnym stanie natury mogła, dzięki małżeństwom, utrzymać je w społeczności rodzinnej - rozproszyły się i błąkały jak zwierzęta po ogromnej puszczy ziemskiej” (\$13). 
żywy (wszystko, co się rusza, musi być żywe) i świadomy (tj. taki, na który można wpływać). Krótko mówiąc, siłą wyobraźni powołali do istnienia pierwszego boga - bóstwo nieba. Na swój obraz i podobieństwo stworzyli Jowisza.

Warto zauważyć, że Vico wystąpił tu przeciwko popularnemu poglądowi, iż idea boga powstała z rozumnej kontemplacji zachwycającego kosmicznego ładu, w którym „niebiosa głoszą chwały Boga”. Zdaniem Vica było dokładnie odwrotnie: idea boga powstała w odruchu obronnym przed przeraźliwym doświadczeniem grozy niebios i chaosu zewnętrznego świata, a fakt, że na szczycie panteonów wszystkich ludów stały bóstwa nieba Zeus, Jowisz, $\mathrm{Baal}^{8}$ - dowodził, że chodziło o uniwersalne doświadczenie pierwotnego przerażenia niebem. Vico odkrył zatem fobiczną genezę politeizmu, który powstał przez potraktowanie przyrody jako ożywionej całości, wypełnionej boskimi siłami (Jovis omnia plena, \$ 379). Całości potężniejszej od człowieka, ale zarazem mu pokrewnej, więc takiej, na którą można wpływać.

W oczach Vica pierwotny człowiek był istotą zalęknioną, ale równocześnie odznaczał się zdolnością metaforyzowania, twórczego przenoszenia samego siebie na to, co nieznane i budzące przestrach: „Zawsze bowiem w podobnej sytuacji [grozy - przyp. R.P.] umysł ludzki przypisuje zjawisku swoją własną naturę [...]” (\$ 377). Innymi słowy - człowiek wychodzi z paraliżującego strachu, animizując i personifikując, a w ten sposób oswajając to, co wzbudzało trwogę.

Pierwszym tworem wylęknionej poetyckiej wyobraźni olbrzymów było wyobrażenie boga. Proces wychodzenia człowieka ze stanu dzikości rozpoczął się zatem od stworzenia religii rozumianej jako lęk przed bogami. Przekonanie, że wynalezienie bogów stanowiło konstytutywny etap przechodzenia od natury do kultury, nie było stanowiskiem nowym i spotykamy je już w starożytności, bodaj najwyraźniej w pochodzącym z V wieku p.n.e. tzw. fragmencie Syzyfa - dramacie satyrowym przypisywanym Kritiaszowi lub Eurypidesowi, w którym czytamy m.in., że po ustanowieniu praw,

8 Również Jahwe pierwotnie miał cechy bóstwa nieba; zob. A. Passoni Dell'Acqua, YHWH come dio della tempesta, [w:] A Necessary Task Essays on Textual Criticism of the Old Testament in Memory of Stephen Pisano, eds. D. Candido, L. Pessoa da Silva Pinto, Roma 2020, s. 51-88. 
kontrolujących postępowanie ludzi „od zewnątrz”, wymyśleni zostali bogowie, mający oddziaływać na postępowanie ludzi „od wewnątrz”. W czasach Vica głównym rozsadnikiem takiej wizji religii był anonimowy traktat $D e$ tribus impostoribus, demaskujący religię jako polityczną fikcję, obliczoną na wywołanie posłuszeństwa poddanych. W świetle rozprawy wiara w bogów stanowiła wymysł władców czy legislatorów, mający na celu z jednej strony wzmocnienie autorytetu praw, z drugiej - wprowadzenie lęku przed boską karą jako środka odstraszania przed popełnianiem zbrodni ${ }^{10}$.

Vico podjął polemikę z traktowaniem religii jako formy religii politycznej. Podzielał pogląd, że religia, będąc tworem samych ludzi, w istocie sprowadza się do lęku przed bogami. Zgadzał się także, że stanowiła instrument społecznej kontroli. Dodawał jednak, że chodziło w niej o wynalazek „fałszywych” bóstw bałwochwalczych kultów pogańskich, co nie dotyczyło chrześcijaństwa; a wynalazek religii nie był dziełem cynicznych politycznych oszustów, lecz płodem przerażonej wyobraźni pierwszych ludzi-poetów:

Tak oto poeci-teologowie zmyślili pierwszą boską baśń najwznioślejszą ze wszystkich, jakie kiedykolwiek później powstały, baśń o Jowiszu gromowładnym, królu i ojcu ludzi oraz bogów. Baśń ta upowszechniła się tak dalece

9 „Był czas, kiedy ludzie wiedli życie nieuporządkowane, podobne życiu dzikich zwierząt i podległe sile [...]. Wtedy to, jak sądzę, ludzie ustanowili karzące prawa, by sprawiedliwość władała wszystkimi jednakowo [...]. Dalej, kiedy prawa sprawiły, iż nie popełniano jawnych zbrodni, popełniano je ukradkiem; i wtedy to, jak sądzę, mąż przemyślny i mądry wpadł na myśl, że trzeba w y nale źć lęk przed bo ga mi, aby istniało coś, co odstrasza złych wtedy, gdy czynią, mówią lub zamyślają coś po kryjomu" (podkr. - R.P.). Bogowie zostali wymyśleni i usytuowani w górnym kręgu wszechświata, dlatego że to on najbardziej napełnia strachem człowieka, który „widział błyskawice i słyszał napawające przerażeniem huki piorunów”; Kritias, Syzyf, tłum. J. Gajda, [w:] J. Gajda, Sofiści, Wiedza Powszechna, Warszawa 1989, s. 288-289. Zob. też: C. Kahn, Greek Religion and Philosophy in the Sisyphus Fragment, „Phronesis” 1997, Vol. 42, No. 3, s. 247-262.

10 Traktat o trzech szalbierzach [De tribus impostoribus], tłum. T. Włodarczyk, [w:] Filozofowie o religii, wyb., wstęp i przypisy A. Nowicki, Warszawa - Kraków 1960, s. 11-32. Vico podkreśla: „,fałszywe religie powstały nie w wyniku szalbierstwa, ale łatwowierności” (\$191). Zob. też: J. Assmann, Monoteizm jako teologia polityczna, tłum. Ł. Kołoczek, „Znak” 2018, nr 762 (listopad), s. 59-60. 
i takie wywołała wrażenie, że sami jej twórcy uwierzyli w nią i ta sama wiara

[...] wzbudziła w nich w stosunku do Jowisza cześć, lęk i posłuch (\$379).

Generalnie rzecz ujmując, chodziło nie o oszustwo i manipulację, lecz łatwowierność, naiwną wiarę w to, co się samemu wymyśliło.

W swej narracji Vico posłużył się znanym toposem epikurejskim: „Strach [...] stworzył na świecie bogów [...]” (\$382). Przez maksymę primos in orbe deos fecit timor ${ }^{11}$ (\$191) epikurejczycy rozumieli, że wyobrażenie sił nadprzyrodzonych było pokłosiem ludzkiej ignorancji - niewiedzy co do rzeczywistych przyczyn zjawisk natury. Dogłębnie studiowany przez Vica w latach młodości Lukrecjusz pisał:

I skąd jeszcze teraz bierze się w ludziach ta straszna trwoga,

Co wznosi po całym świecie wciąż nowe przybytki bogów $[\ldots]^{12}$.

Nie mogli zaś wyrozumieć, z jakich to dzieje się przyczyn.

Uciekli się więc do tego, że wszystko oddali bogom,

I wymyślili, że wszystko zależy od ich skinienia (V. 1185-1188).

Co więcej, także dla Lukrecjusza źródłem największego przestrachu było niebo:

Po niebie bowiem widomie przetacza się noc i księżyc [...],

Pioruny, gwałtowne grzmoty i głuche, groźne pomruki.

Jakże nieszczęsnym ród ludzki stał się, gdy bogom przypisał

Tak wielkie dzieła i przydał im skłonność do srogich gniewów! (V.1189-1196)

W oczach Lukrecjusza religia była jednak czymś groźniejszym niż tylko prymitywną reakcją owładniętego strachem umysłu, bowiem sama eskalowała strach, stanowiąc największą przeszkodę na drodze do szczęścia, ale także istotną pobudkę do czynienia zła, bowiem przeświadczenie, że obraza bóstwa ściąga na człowieka jego gniew i zemstę, niezmiennie skłaniało ludzi do prób uwolnienia się od winy za pomocą darów. W trwodze starano się

11 Bogów na świecie pierwszy stworzył strach.

12 Lukrecjusz, O naturze rzeczy, tłum., wstęp i komentarze G. Żurek, Warszawa 1994, V. 1166-1167; dalsze cytaty według tego wydania lokalizuję bezpośrednio w tekście. 
uśmierzyć gniew bogów i zaskarbić sobie ich przychylność poprzez ofiary, poświęcając bogom to, co najcenniejsze, w tym innych ludzi, także własne dzieci. Znamienne, że Lukrecjusz otworzył swój poemat obrazem złożenia w ofierze Ifigenii (O naturze rzeczy, I. 80-111), poświęconej Artemidzie dla uśmierzenia jej gniewu ${ }^{13}$. Rzymski poeta upatrywał w rytuale ofiarnym emblemat religijnego zabobonu, który skłaniał ludzi ogarniętych strachem do wstrząsających mordów: „Do takich szczytów zła mogła doprowadzić ludzi religia” (Tantum religio potuit suadere malorum, I. 101). Lukrecjusz upatrywał w religii - lękowej reakcji na świat - główną przyczynę zła w życiu ludzkim. W swym poemacie proponował naukę epikurejską jako skuteczne remedium na lęk traktowany jako najcięższą z chorób duszy ${ }^{14}$.

Vico nie miał złudzeń, że pierwsi ludzie, okrutni i dzicy, składali krwawe ofiary z ludzi. Jednak, wbrew Lukrecjuszowi, włoski filozof usprawiedliwiał religię wraz z jej ofiarami, a to za jej zasługi na polu okiełznywania dzikości i doprowadzania człowieka do życia cywilizowanego ${ }^{15}$. Choć zatem bogowie byli wytworem ludzkiego strachu, a religia była równoznaczna

${ }_{13}$ M. von Albrecht, „Terror et pavor”: politica e religione in Lucrezio, [w:] „Terror et pavor". Violenza, intimidazione, clandestinità nel mondo antico (Atti del convegno internazionale, Cividale del Friuli, 22-24 settembre 2005), ed. G. Urso, Pisa 2006, s. 231-245; zob. też: R. Brown, Lucretius' use of the name Iphianassa (De Rerum natura 1.85), „The Classical Quarterly” 2019, Vol. 69, Issue 2, s. 1-10, DOI: 10.1017/ S0009838819000946.

${ }^{14}$ Celem poematu Lukrecjusza było uwolnienie Rzymian od lęku. Lukrecjusz przyjmuje, że lęk jest korzeniem religii, a religia stanowi główny wspornik rzymskiego państwa. Proponuje remedium na lęk, którym jest nauka „boskiego wybawiciela” - Epikura (V.10-13). Atomistyczna fizyka, racjonalnie objaśniająca zjawiska przyrody, uwalnia od lęku przed interwencją boskich sił. Epikurejska teologia, uznająca $\mathrm{w}$ bogach niedościgniony model szczęśliwości, eliminuje wyobrażenie bogów domagających się od ludzi ofiar. Innymi słowy, Lukrecjuszowa „teologia wyzwolenia" wyswobadza z religijnej niewoli, otwierając drogę życiu szczęśliwemu, tj. wolnemu od lęku; zob. M. von Albrecht, op. cit., s. 238.

15 „Tak więc nieszczęsny ślub oraz ofiara złożona przez Agamemnona z jego własnej pobożnej córki Ifigenii [...] nastąpiła z woli opatrzności. Ofiary te były bowiem potrzebne dla okiełznania potomków Polifema i przekształcenia ich w cywilizowanych Arystydesów i Sokratesów, Leliuszów i Scypionów Afrykańskich" (\$191). 
z trwogą wobec wyimaginowanych mocy, to ów strach, fikcje i ofiary przyniosły ludziom zasadniczą korzyść - samokontrolę ${ }^{16}$. Paniczny strach przed boskimi siłami, karzącym gromem Jowiszem, bogami wymierzającymi sprawiedliwość tym, którzy czynią zło, zmuszał na wpół dzikie istoty do samoopanowania (\$502): „Otóż tylko wzbudzająca grozę myśl o jakimś bóstwie mogła poskromić ich potworną dzikość i potworną nieokiełznaną zwierzęcą wolność” (\$338); utrzymując w karbach namiętności, religia ustanawiała życie społeczne. Vico określił swoje dzieło mianem „rozumowej teologii politycznej boskiej opatrzności” (teologia civile ragionata della provvedenza divina, $\$ 366)^{17}$, podkreślając w ten sposób, że badał wkład religii

16 „A więc metafizyka poetów-olbrzymów, w swej bezbożności walczących z niebem, pokonała ich grozą Jowisza, którego poznali jako gromowładnego. Pognębieni na ciele nie mniej niż na duchu powzięli straszliwe pojęcie o Jowiszu" (\$502). „Pobożność wywodzi się z religii, która we właściwym tego słowa znaczeniu jest lękiem wobec bóstwa" (\$503).

17 Vico nawiązał do podziału teologii zaproponowanego przez rzymskiego polihistora Marca Terencjusza Warrona, który - za stoikami - wyróżnił trzy jej rodzaje: „teologię mityczną”, uprawianą przez poetów, „teologię naturalną” filozofów, widzących w opowieściach o bogach alegorezy sił natury, oraz „teologię obywatelską" (theologia civilis), przez którą rozumiał kult państwowy uprawiany przez kapłanów i obywateli. Dzieło Warrona, Antiquitates rerum humanarum et divinarum (47 r. p.n.e.), zaginęło, ale sam podział pozostał znany m.in. dzięki św. Augustynowi (O Państwie Bożym [De civitate Dei]: przeciw poganom ksiag XXII, IV.27; VI.5-6; VI 12; VIII, 1, tłum. i oprac. W. Kornatowski, Warszawa 1977). To, że greckim odpowiednikiem „teologia civilis” jest „teologia polityczna”, mówi sam św. Augustyn (ibidem, VI, 12: „Nunc propter tres theologias, quas Graeci dicunt mythicen physicen politicen, Latine autem dici possunt fabulosa naturalis civilis"). Tłumaczenie teologia civile w polskiej edycji Nauki nowej jako "teologia społeczna” (\$366) nie tylko zaciera związek z trójpodziałem Warrona, ale także z wielką tradycją refleksji nad znaczeniem religii w kształtowaniu się życia wspólnotowego. Na temat trójpodziału teologii zob. J. Pépin, La "Théologie tripartite” de Varron. Essai de reconstitution et recherche des sources, „Revue des Études Augustiniennes” 1956, Vol. 2, s. 265-294; G. Lieberg, The Theologia Tripartita as an Intellectual Model in Antiquity, [w:] Essays in Memory of Karl Kerényi, ed. E.C. Polomé, Washington 1984, s. 91-115; J. Rüpke, Varro's tria genera theologiae: religious thinking in the late Republic, „Ordia Prima” 2005, Vol. 4, s. 107-129. 
w dzieło ukonstytuowania się życia wspólnotowego człowieka ${ }^{18}$, że nauka nowa to alternatywna postać teologii politycznej.

\section{CO POWIEDZIAŁ GROM}

Pierwszym wspólnototwórczym skutkiem religijnego strachu przed piorunem i niewidzialnymi mocami były monogamiczne związki - „najpierw w oparciu o religie powstały rodziny, później zaś utworzyły się państwa oraz prawa” (\$14), Dla Vica dzikość bestioni manifestowała się w nieregulowanych żadną normą stosunkach seksualnych. W promiskuityzmie widział bowiem synonim nieopanowania, a małżeństwo, wraz z praktyką grzebania zmarłych, traktował jako pierwszą oznakę życia cywilizowanego. Vico należał zatem do tych myślicieli, którzy w ograniczeniach nałożonych na życie seksualne upatrują pierwszy zakaz ustanawiający egzystencję wspólnotową, a tym samym moment przejścia od barbarzyństwa do życia prawdziwie ludzkiego.

W jaki sposób dokonał się ów krok ku poskromieniu instynktów? Według Vica pierwsza burza po potopie zaskoczyła olbrzymów in flagranti, toteż łoskot grzmotów odebrali oni jako głos Jowisza wyrażającego dezaprobatę. Pierwszy huk został potraktowany jako wyraz boskiego gniewu i żądanie powściągliwości, czyli ustanowienie pierwszego zakazu ${ }^{19}$. Od tej pory podkreślał Vico - olbrzymi z kobietami kryli się przed piorunami Jowisza w jaskiniach: „Tak powstało małżeństwo, czyli związek cielesny uprawiany wstydliwie, w lęku przed bóstwem” (\$505), dając początek pierwszym rodzinom, a w konsekwencji również osiadłemu trybowi życia ${ }^{20}$. Religijny strach

18 Św. Augustyn krytykował teologię polityczną jako teologię sztucznie stworzoną i obliczoną na wspieranie rzymskiego państwa. Vico zdaje się rehabilitować teologię polityczną jako namysł nad wkładem religii w ustanowienie życia społecznego.

19 „Początkiem naturalnym cnoty było opanowanie [conato]. Pod wpływem religii zrodzonej ze strachu przed piorunami żyjący w jaskiniach podgórskich olbrzymi powstrzymali swój zwierzęcy pęd do błąkania się po rozległej ziemskiej puszczy. Potem nauczyli się zupełnie innego trybu życia, spokojnego i w ukryciu, i stali się założycielami narodów i władcami pierwszych republik” (\$504).

20 „Opanowanie uczyniło cnotliwym ich ducha, powstrzymując ich od zaspokajania żądzy zwierzęcej w obliczu nieba, które budziło w nich niezmierną 
pozostał spoiwem życia patriarchalnych rodzin, w których wszechwładny ojciec (pater familias) sprawował nad potomstwem władzę absolutną. Jego autorytet legitymizowało niebo: uważał się za potomka bogów, w imieniu których sprawował władzę. Do wyłącznych prerogatyw ojców należała interpretacja „mowy bogów” - znaków nieba, z których odczytywali ich wolę. Władza ojców miała zatem charakter kapłański (\$250). Sposobem na zrozumienie „mowy bogów” było wróżenie, a piorun był podstawowym znakiem wróżebnym. Każdy naród zaczynał od wróżenia z błyskawic i grzmotów swego Jowisza ${ }^{21}$.

W ten sposób neapolitański filozof odrzucił podstawowy teoremat klasycznej filozofii politycznej, według którego fundamentem wspólnoty obywatelskiej było dążenie do najlepszego ustroju lub wspólnego dobra ${ }^{22}$. Podobnie jak Niccolò Machiavelli i Thomas Hobbes Vico zastąpił koncepcję idealistyczną podejściem realistycznym: skoro pierwotni ludzie byli istotami dążącymi przede wszystkim do przetrwania, czyli zachowania swego życia, skutecznym spoiwem społecznym w żaden sposób nie mógł być rozumowy ideał. Musiała być nim trwoga, proporcjonalna do stanu dzikości pierwszych ludzi. Strach był, zdaniem Vica, podstawowym czynnikiem wspólnototwórczym, ale także naczelnym instrumentem władzy. Państwo powstało w celu

grozę. Każdy uprowadzał zatem dla siebie w głąb jaskini jedną kobietą, jako stałą towarzyszkę życia” (\$504). Motyw ukrycia w jaskini z lęku przed bogami Vico zaczerpnął od Lukrecjusza:

„[...] komuż serca nie ściska lęk przed bogami,

Któż z trwogi nie chciałby wślizgnąć się do najgłębszej kryjówki,

Gdy drży i pali się ziemia, rażona straszliwym ciosem

Gromu, i łoskot się niesie po całym ogromnym niebie?” (V. 1219-1222).

${ }^{21}$ „A pierwsi ludzie, którzy porozumieli się za pomocą znaków, wierzyli [...], że grzmoty i pioruny są znakami Jowisza. [...] Jowisz miał więc rządzić za pomocą znaków, które były przedmiotowymi słowami [parole reali], a natura miała być jego językiem. Wiedzę o tym języku [...] stanowiło wróżbiarstwo, które Grecy nazwali »teologią«, tj. »wiedzą o mowie bogów«" (\$ 379).

22 F. Vaughan, The Political Philosophy of Giambattista Vico: An Introduction to La Scienza Nuova, The Hague 1972, s. 35; A. Zając, Polityka poetycka Giambattisty Vica, „Politeja” 2017, nr 46, s. 353-376. 
uwolnienia ludzi od zagrożenia życia i zagwarantowania bezpieczeństwa, ale do osiągnięcia tych celów samo skutecznie posługiwało się strachem ${ }^{23}$.

W najdawniejszych państwach, utworzonych „ze związku sprawujących władzę rodzinną ojców” (\$25), źródłem autorytetu pozostawało niebo. Vico nazywał je państwami teokratycznymi, bowiem ludzie „wierzyli, że żyją pod rządami boskimi, a wszelkie nakazy otrzymują za pomocą wróżb i wyroczni” (\$31). Stąd w państwach tych istniały rozbudowane techniki odkrywania woli Jowisza, czytania znaków, za pomocą których bóstwo komunikowało swe rozkazy ${ }^{24}$. Vico nie miał wątpliwości, że najstarsze normy ludzkie miały charakter sakralny („Wszędzie zatem pierwsze prawa były boskie, Jowiszowe" [ $\$ 482]$ ) i związek prawa z Jowiszem dostrzegał nawet w etymologii słowa „prawo” (ius):

Pierwsi ojcowie narodów pogańskich byli sprawiedliwi, gdyż ze zbożną wiarą przestrzegali wróżb, które uważali za rozkazy boskie Jowisza. Od niego to, nazywanego u Latynów Ious, wywodzi się starożytne ious, skrócone następnie do ius - „prawo” i dlatego u wszystkich narodów sprawiedliwość wiąże się w sposób naturalny z pobożnością (\$14).

Prawa miały siłę emocjonalnego oddziaływania dlatego, że budziły postrach równy epifanii Jowiszowego pioruna. Przestrzegano ich, gdyż wiązały się z karą ze strony gromowładnego bóstwa - przestępstwo rozumiano jako jego obrazę, dobrem było zaś wszystko, czego ono żądało.

\section{JEZZYK I STRACH}

Jednocześnie z wizją narodzin religii i życia społecznego Vico zaproponował hipotezę powstania języka ${ }^{25}$. W jego interpretacji olbrzymi utracili mowę,

${ }^{23}$ Zob. J. Freund, Le thème de la peur chez Hobbes, „Revue Européenne des Sciences Sociales" 1980, T. 18, No. 49, s. 13-32; C. Ginzburg, Strach, terror i cześć, tłum. M. Warchala, „Przegląd Polityczny” 2018, nr 147, s. 86-94.

24 „Zgodnie z tymi zasadami wszystkie cnoty winny być zakorzenione w pobożności i religii, gdyż tylko wówczas stają się skuteczne, ludzie zaś uznają za dobre to wszystko, czego żąda Bóg” (\$14).

${ }^{25} \mathrm{Na}$ temat Vikiańskiej koncepcji języka zob. G. Cantelli, Gestualità e mito: $i$ due caratteri distintivi della lingua originaria secondo Vico, „Bollettino Del Centro di Studi Vichiani" 1990, Vol. 20, s. 77-116; J. Trabant, Vico's New Science of Ancient 
którą Adam posługiwał się w Raju. Mowa olbrzymów nie była już zatem darem Boga, ale dziełem samych ludzi. Włoski filozof rozróżniał trzy rodzaje języka, odpowiadające trzem epokom dziejów ludzkości: boski - w epoce teokratycznej, heroiczny - w epoce bohaterów, a także ludzki - w epoce demokratycznej. Pierwszy z nich „był to język niemy, znaków lub rzeczy, związanych w naturalny sposób z pojęciami, jakie miały wyrażać” (\$ 32). Rzecz znamienna, Vico nie utożsamiał języka ani ze znakami dźwiękowymi, ani znakami pisma. Pierwotnie język nie był zatem mową - systemem dźwięków. Mowę poprzedzał język gestów, wskazań i znaków; „język niemy”, zmysłowy i konkretny (por. $\$ 434-435$ ). Umysł początkowo pojmował wszystko w sposób konkretny, toteż pierwsze „słowa” miały charakter deiktyczny. Jak zauważył Jürgen Trabant, były one znakami, materialnymi przedmiotami i gestami obdarzonymi znaczeniem ${ }^{26}$. Zatem, według Vica, pierwszy znak ukonstytuował się wraz ze wskazaniem na firmament jako na gromowładne bóstwo. Niebo jednak nie oznaczało jeszcze Jowisza, lecz było Jowiszem, bowiem rozróżnienie znaku i znaczenia wyłoniło się w długotrwałym procesie przechodzenia od tego, co konkretne, do związanej z nazwami ogólności. A zatem - język boski epoki teokratycznej nie był słyszalny, lecz widzialny ${ }^{27}$.

Vico sytuował początek mowy dopiero w epoce heroicznej. Podkreślał, że pierwotnie nie wiązała się ona z kwestią prawdziwości, lecz służyła ekspresji namiętności. Prymitywni ludzie reagowali na świat w sposób emocjonalny: gestami i odgłosami. Swe „gwałtowne i burzliwe namiętności umieli wyrażać tylko wyciem i pomrukami” (\$377). Pod wpływem gwałtownych uczuć i traumatycznych doznań nieme bestie zaczęły wydawać z siebie

Signs: A Study of Sematology, London 2004; J. Kreuzer, Zmysłowość języka, tłum. K. Krzemień-Ojak, „Prace Kulturoznawcze” 2014, t. 16, s. 181-196.

${ }^{26}$ J. Trabant, op. cit., s. 26. „W ten właśnie sposób poeci-teologowie pojmowali - by posłużyć się przykładami - Jowisza, Kybelę lub Bercyntię i Neptuna. Niemi, wskazując ich za pomocą gestu, tłumaczyli, że są to substancje niebieskie, ziemskie i morskie, które wyobrażali sobie jako ożywione bóstwa i wierząc zmysłom, uznawali za bogów” (\$402).

${ }^{27}$ Tę intuicję Vica rozwinął niemiecki teoretyk obrazu i kulturoznawca Aby Warburg; zob. E. Kwiatkowska, Vikiański ślad w warburgiańskiej tradycji kulturoznawczej, „Prace Kulturoznawcze” 2014, t. 16, s. 125-138. 
monosylabiczne dźwięki, które następnie utrwalały się w pierwsze słowa. Okrzyk przerażenia, jęk bólu, ryk wściekłości, pomruk zawodzenia można uznać za pra-słowa. W procesie kształtowania się najstarszych słów wielką rolę odegrała onomatopeja: wyobrażenie, że Jowisz „za pośrednictwem błyskawic i łoskotu gromów chciał do nich [ludzi - przyp. R.P.] przemówić” (\$377), związane było ze skojarzeniem huku pioruna z rykiem wydawanym przez olbrzymów.

A dalej, wraz z powstaniem boskiego symbolu Jowisza [...] zaczął również tworzyć się język artykułowany dzięki onomatopei, którą, jak to łatwo możemy obserwować, posługują się zawsze z powodzeniem dzieci. Owego Jowisza Latynowie zwali początkowo od huku grzmotów Ious, Grecy, od błysku pioruna Zev́ৎ $(\$ 447)^{28}$.

Heroiczny okres języka polegał na nadawaniu rzeczom nazw i do tego sprowadzało się najbardziej spektakularne dokonanie pierwotnych ludzi dzięki temu zasłużyli sobie na miano poetów. Byli poetami w źródłowym sensie słowa, tj. twórcami świata, nazywanie bowiem to akt kreacji świata ludzkiego, projektowania na naturalne przedmioty samych siebie i przeobrażania ich w jestestwa żywe ${ }^{29}$. Spowicie świata welonem nazw służyło przeobrażaniu tego, co obce i groźne, w to, co oswojone i uczłowieczone.

Vico nazywany bywa odkrywcą językowej natury świata społecznego ${ }^{30}$. Podkreślał, że „człowiek składa się w istocie z umysłu, ciała i mowy, przy czym ta ostatnia pośredniczy między umysłem a ciałem” (\$ 1045). Język był zatem najważniejszym narzędziem odzyskania przez bestioni utraconego człowieczeństwa i warunkiem powstania rzeczywistości społecznej.

${ }^{28}$ Vico sugeruje związek pierwszych słów z doświadczeniami człowieka; przekonanie, że w nazwach rzeczy kryją się ślady prastarych, silnych doznań ludzkich, do których jest w stanie dotrzeć etymologia; zob. E. Zwolski, Z historii badań nad religia i mitem. Friedrich Max Müller, czyli dialektyka religii i mitologii, „Roczniki Humanistyczne" 1978, t. 26, z. 2, s. 18.

29 „Najbardziej wzniosłą czynnością poezji jest przypisywanie rzeczom martwym czucia i namiętności” (\$ 186). O związkach Vico z antyscholastycznymi teoriami języka zob. A. Zając, op. cit.

30 Zob. H. White, Tropika historii: struktura głęboka „Nauki Nowej”, [w:] idem, Poetyka pisarstwa historycznego, tłum. E. Domańska, Kraków 2000, s. 237-267. 


\section{HERMANNA USENERA BÓSTWO BŁYSKAWICY}

W Nauce nowej prekursorskie i niezmiennie inspirujące intuicje sąsiadują z tym, co dzisiaj wydaje się anachroniczne lub jawnie błędne. Erich Auerbach, jeden $\mathrm{z}$ najważniejszych dwudziestowiecznych kontynuatorów projektu neapolitańskiego myśliciela, zauważył:

Opętany swą wizją, zbyt ubogi w materiały, by dowieść jej prawdziwości (brakowało wszak całego materiału etnologicznego, orientalistycznego, średniowiecznego, który ujawniono od tamtych czasów), interpretował antyczne świadectwa, które miał do dyspozycji: mity, źródła i znaczenia wyrazów, ustępy tekstów poetów, historyków, prawników, często zadając im gwałt. Niekiedy zapomniał lub przeoczył to, co współcześni mu uczeniu zbadali już lepiej ${ }^{31}$.

W istocie, dopiero po śmierci Vica Europa odkryła sanskryt, a odkrycie to skierowało filologię na nowe tory. Podobieństwo sanskrytu do języków europejskich umożliwiło studia porównawcze nad indoeuropejską rodziną językową. W rezultacie narodziło się językoznawstwo porównawcze, którego owocem była m.in. etymologia. W jej świetle większość Vikiańskich źródłosłowów okazała się zmyślona. Łatwo też dzisiaj zakwestionować silnie zakorzenione przekonanie Vica o uniwersalnej ważności Rzymu, które sprawiało, że swobodnie ekstrapolował on rzymskie dzieje jako doświadczenia charakterystyczne dla całej ludzkości. Problematyczne może wydawać się wreszcie redukcjonistyczne potraktowanie pierwszego gromu jako detonatora kulturowego „wielkiego wybuchu”, z którego jednocześnie wyłoniły się religia, życie społeczne, prawa oraz język.

Jednak hipoteza grozy, zwłaszcza grozy nieba, jako czynnika religiotwórczego nie została kompletnie zarzucona: 180 lat po pierwszym wydaniu Nauki nowej znalazła wsparcie w pracy niemieckiego filologa Hermanna

${ }^{31}$ E. Auerbach, Język literacki i jego odbiorcy w późnym antyku łacińskim i średniowieczu, tłum. R. Urbański, Kraków 2006, s. 22. 
Usenera (1834-1905) ${ }^{32}$, który jedno ze swych ostatnich studiów poświęcił omówieniu świadectw kultu Pioruna w grecko-rzymskiej starożytności ${ }^{33}$.

Usener należał do najbardziej wpływowych przedstawicieli niemieckiej filologii końca XIX wieku, tj. epoki, w której okrzepła już ona jako dyscyplina naukowa. Choć filologia kojarzyła się wówczas przede wszystkim z tradycją edycji tekstów źródłowych, to związek z projektem Vica pozostał. Wydawanie i interpretacje tekstów poetyckich, mitologicznych, świadectw historiograficznych czy źródeł prawnych traktowano jako etap wstępny do rekonstrukcji początków poszczególnych narodów europejskich ${ }^{34}$. W ostatecznym rachunku, filologii nadal przyświecał cel antropologiczno-kulturoznawczy: dotarcie do „istoty” czy „charakteru” narodu.

Sam Usener rygorystyczny aparat filologiczny wzorcowo zastosował do edycji tekstów, wśród których wyróżnia się szczególnie wydanie źródeł dotyczących Epikura i epikureizmu ${ }^{35}$. Filologię Usener uważał nie tyle za naukę, co metodę interpretacji faktów historycznych ${ }^{36}$. Na przełomie XIX

${ }^{32} \mathrm{Na}$ temat biografii intelektualnej Usenera zob. J.N. Bremmer, Hermann Usener, [w:] Classical Scholarship. A Biographical Encyclopedia, eds. W.W. Briggs, W.M. Calder III, New York - London 1990, s. 462-478; Aspetti di Hermann Usener filologo della religione, ed. G. Arrighetti [et al.], Pisa 1982; Hermann Usener und die Metamorphosen der Philologie, Hrsg. von M. Espagne, P. Rabault-Feuerhahn, Wiesbaden 2011.

33 H. Usener, Keraunos, Ein Beitrag Religiöser Begriffsgeschichte, „Rheinisches Museum Für Philologie” 1905, Bd. 60, s. 1-30 (polski przekład zob. Keraunos. Przyczynek do historii pewnego wyobrażenia religijnego, tłum. P. Napiwodzki; w niniejszym tomie, s. 619-670).

34 Zob. J. Leerssen, The Rise of Philology: The Comparative Method, the Historicist Turn and the Surreptitious Influence of Giambattista Vico, [w:] The Making of the Humanities II: From Early Modern to Modern Disciplines, eds. R. Bod, J. Maat, T. Weststeijn, Amsterdam 2012, s. 23-35.

35 Epicurea, Hrsg. von Hermannus Usener, Lipsiae 1887. Zob. I. Ramelli, Usener's Work on Epicurus, [w:] Hermann Usener und die Metamorphosen der Philologie, op. cit., s. 153-170. Praca Usenera inspirowała kolejne pomnikowe edycje np. H. Dielsa (Die Fragmente der Vorsokratiker, Berlin 1903) czy Hansa von Arnima (Stoicorum Veterum Fragmenta, Leipzig 1903-1905).

36 Zob. H. Usener, Philologie und Geschichtswissenschaft, [w:] idem, Vorträge und Aufsätze, Leipzig 1907, s. 2-35. (Philologie et sciences historiques [1882], „Revue germanique internationale" 2011, Vol. 14, s. 155-178, DOI: 10.4000/rgi.1283). 
i XX wieku, w momencie gdy religia stawała się ważnym przedmiotem zainteresowań badawczych, a religioznawstwo formowało się w odrębną dyscyplinę naukową, filologiczne metody interpretacji zastosował do zagadnień religijnych ${ }^{37}$. Położył tym samym podwaliny pod naukowe religioznawstwo, tworząc w Niemczech jeden z najbardziej znaczących ośrodków studiów nad historią religii ${ }^{38}$.

Jednak Usener pamiętany jest dzisiaj głównie jako autor Götternamen. Versuch einer Lehre von der religiösen Begriffsbildung $(1896)^{39}$ - dzieła, w którym podjął temat genezy politeizmu. Za sposób zmierzenia się z tym zagadnieniem przyjął analizę imion bogów, omawiając nazwy bóstw greckich, rzymskich oraz litewskich. W rezultacie opracował teorię ewolucyjnego kształtowania się pojęć religijnych, którą można rozumieć również jako koncepcję trzech stadiów religii - koncepcję zaliczaną do największych osiągnięć dziewiętnastowiecznego religioznawstwa.

Usener odrzucił popularne przekonanie, że kształtowanie pojęć ogólnych stanowi naturalną operację ludzkiego umysłu. Podobnie jak Vico uważał, że wyobraźnia nie tworzy pojęć, lecz konkretne wyobrażenia, a dochodzenie do pojęć ogólnych polega na powiązanym z nazwami mozolnym wznoszeniu się umysłu do tego, co ogólne. Z tego względu Usener przyjmował, że najdawniejszy etap konstrukcji wyobrażeń religijnych musiał mieć charakter jednostkowy. Twierdził, że u swego zarania ludzie czcili konkretne, jednorazowe

37 Do najbardziej znanych prac Usenera z zakresu badań nad wczesnym chrześcijaństwem należało studium o święcie Bożego Narodzenia, Das Weihnachtsfest (Bonn 1889). Zob. S. Hijmans, Usener's „Christmas”: A Contribution to the Modern Construct of Late Antique Solar Syncretism, [w:] Hermann Usener und die Metamorphosen der Philologie, op. cit., s. 139-151.

38 Zob. H. Treiber, For What Purpose do We Still Read the Protestant Ethic Today?, „Società Mutamento Politica” 2014, Vol. 5, No. 9, s. 30-37, DOI: 10.13128/ SMP-14484. Na temat Usenera jako historyka religii zob. R. Bodei, Hermann Usener nella filosofia moderna: tra Dilthey e Cassirer, [w:] Aspetti di Hermann Usener filologo della religione, op. cit., s. 23-42; A. Momigliano, Hermann Usener, „History and Theory" 1982, Vol. 21, No. 4, s. 33-48; R. Kany, Hermann Usener as Historian of Religion, „Archiv für Religionsgeschichte” 2004, Bd. 6, s. 159-175.

39 H. Usener, Götternamen. Versuch einer Lehre von der religiösen Begriffsbildung, Bonn 1896. Usener rozpoczął badania nad imionami bogów w ramach wykładów uniwersyteckich w 1873 roku; zob. R. Kany, op. cit., s. 163. 
wydarzenia, stanowiące znaczące przeżycie psychiczne. Każdorazowe silne doznanie odbierali jako epifanię bóstwa i z przeżycia tego wywodziło się jego imię, kształtujące się z utrwalonych dźwięków wydawanych w chwili wstrząsu, np. z okrzyku strachu spowodowanego przeżyciem grozy. Nazwy bóstw byłyby zatem upostaciowionym doznaniem.

Takich bogów, objawiających się konkretnie i jednorazowo, Usener określił mianem Augenblickgötter - „bogów chwilowych”. W miarę powiększania się ludzkiej pamięci i zdolności myślenia abstrakcyjnego zaczęły tworzyć się - związane z nazwami - pojęcia ogólne. W procesie rozwoju pojawili się bogowie patronujący poszczególnym sferom życia czy spełniający określoną funkcję. Bóstwom tym Usener nadał nazwę Sondegötter - „bogów specjalnych”. O ile istnienie „bogów chwilowych” miało charakter przypuszczenia, o tyle mówiąc o „bogach specjalnych”, Usener miał na myśli rzymskich di indigetes. Do naszych czasów zachowały się listy imion italskich i latyńskich bogów wraz z ich prerogatywami. Wiemy, że w czasach archaicznych rzymski słownik religijny liczył 30 tys. wyspecjalizowanych bóstw, patronujących każdej czynności, odnoszących się do wszystkich fizycznych przedmiotów i zjawisk (znamienne, że na fakt ten zwrócił uwagę również Vico [\$437]). Bogowie ci nie mieli specyficznej osobowości, nie wiązały się z nimi żadne podania mitologiczne, a ich nazwa była przejrzysta i oznaczała zakres kompetencji.

Dopiero na kolejnym etapie ewolucji pojawiło się pojęcie bogów osobowych, odznaczających się złożoną osobowością, cechami charakterystycznymi i atrybutami; bogów, na temat których zaczęły się pojawiać opowieści (mity). Usener twierdził, że bogowie osobowi wyłonili w procesie ewolucji Sondegötter, a „bogowie specjalni” zostali sprowadzeni do roli „epitetów” czy atrybutów owych bóstw osobowych.

Opublikowane w 1905 roku studium Keraunos to podsumowanie refleksji Usenera na temat kształtowania się pojęć religijnych. Tym razem swą teorię niemiecki filolog zaprezentował na przykładzie bóstwa Błyskawicy. Zebrał ogromy materiał źródłowy, grecki i rzymski, zarówno tekstualny, jak i ikonograficzny, na podstawie którego wnosił, że w archaicznych czasach Grecy i Rzymianie czcili Piorun jako samodzielne bóstwo. Innymi słowy, Usener zakwestionował pogląd, że Piorun był wyłącznie atrybutem Zeusa. Jego zdaniem w czasach archaicznych Keraunos był najsilniejszą obok Zeusa, całkowicie niezależną od niego istotą boską. Na podstawie reliktów kultu Keraunosa, niekiedy późnych, bo pochodzących z epoki hellenistycznej, 
Usener wnosił o rzeczywistości archaicznej. Wychodził bowiem z założenia, że ludowe wierzenia i zwyczaje zachowują relikty archaicznych podań i rytuałów, nawet jeśli kontekst religijny, do którego pierwotnie owe relikty przynależały, przestał już istnieć. Podobnie jak Edward B. Tylor Usener wierzył w istnienie tzw. survivals, pozwalających wniknąć w najdawniejsze warstwy myśli religijnej ${ }^{40}$.

W jaki sposób zatem powstało religijne pojęcie Keraunosa? W ten sam, $\mathrm{w}$ jaki pozostałe pojęcia religijne, tj. od konkretnego, jednostkowego doświadczenia uderzenia gromu. Początkowo każda błyskawica była odbierana jako epifania bóstwa. Wierzono, że bóstwo zstępowało z nieba pod postacią pioruna i brało w posiadanie rażone miejsce, które uważano odtąd za święte, odgradzając od sfery profanum. Wznoszono na nim ołtarz, gdzie specjalni kapłani składali ofiary (narracja Usenera zaczyna się od wspomnienia odkrytego w Mantinei kamienia z V wieku p.n.e. z inskrypcją „Zeusowi Piorunowi” - kamień ten zaznaczał miejsce rażone piorunem). Także osoby trafione piorunem czczono jako wybrańców bogów. Wbrew twierdzeniu Vica trafienie piorunem w Grecji uważano za oznakę wybraństwa, a nie gniewu.

Każde uderzenie pioruna było zatem epifanią Keraunosa, który w kategoriach Usenera był wzorcowym przykładem „boga chwilowego”. Tak jak u Vica zatem, pierwszy grom był początkiem religijnego kultu, którego obiektem była zstępująca $\mathrm{z}$ nieba boska siła. Podkreślmy: Keraunos początkowo nie oznaczał więc boga, ale był bogiem manifestującym się w błyskawicy. Dopiero na kolejnym etapie ewolucji pojęcia zaczęło ono być rozumiane ogólnie, a Keraunos stał się bogiem specjalnym, tj. oznaczającym wszystkie błyskawice.

Początkowa wielość uległa dalszej kondensacji z chwilą, gdy Keraunos został przeniesiony na Zeusa, stając się jednym z jego atrybutów. Siła Zeusa, który zyskał przydomek „Piorunowy” (Keraunios), manifestowała się najbardziej w jego broni - piorunach, nie tylko powodujących śmierć i zniszczenie

40 Zob. E.B. Tylor, Primitive Culture, London 1871 (wyd. pol. Cywilizacja pierwotna. Badania rozwoju mitologji, filozofji, wairy, mowy, sztuki i zwyczajów, t. 1, tłum Z.A. Kowerska, wstęp i oprac. J. Karłowicz, Warszawa 1896). Na temat koncepcji survivals zob. G. Didi-Huberman, The Surviving Image: Aby Warburg and Tylorian Anthropology, „Oxford Art Journal” 2002, Vol. 25, No. 1, s. 61-69. 
(pożogę), ale których sam widok i efekt dźwiękowy napawał śmiertelnym przerażeniem.

Twierdzenie Usenera, że Keraunos, zanim stał się atrybutem Zeusa, był osobnym bóstwem, stało się przedmiotem sporu badaczy ${ }^{41}$. Nie ulega jednak wątpliwości, że Piorun, czy to jako samodzielne bóstwo, czy to jako broń Zeusa, był obiektem religijnego kultu. Wyprowadzając imiona boga z pierwotnej reakcji na świat, Usener - choć w swym tekście nie wspominał $\mathrm{Vica}^{42}$ - rozwinął jego intuicję, zgodnie z którą pierwotni ludzie widzieli epifanię boskości we wszystkim, z czym się stykali, a religia tkwiła swymi korzeniami w pierwotnych reakcjach człowieka na świat, zwłaszcza reakcjach fobicznych.

\section{PODSUMOWANIE}

W połowie XVII wieku potwierdzony został elektromagnetyczny charakter pioruna. Błyskawica przestała być wyładowaniem gniewu boga, a stała się wyładowaniem atmosferycznym. Zamiast być atrybutem absolutnej boskiej władzy, okazała się elektryczną iskrą, którą od 1752 roku można było już częściowo kontrolować. Wynalazcę piorunochronu, Benjamina Franklina, witano jako nowego Prometeusza, który „wyrwał niebiosom piorun, a berło tyranom"43.

Od czasu oświecenia nauka i technika awansowały do rangi głównego narzędzia wyzwalania od lęku. Podbój świata i opanowywanie natury miały

${ }^{41}$ Holenderski badacz Jan Maarten Bremmer zauważył: „It might be the case that in prehistoric times Greeks worshipped the lightning as a separate divine power, but it will never be possible to prove it, however much Usener would like to"; J.M. Bremmer, Zeus' Lightning in Early Greek Myth and in Cleanthes' Hymn, „Roczniki Humanistyczne. 3. Filologia Klasyczna” 2006-2007, t. 54-55: Ksiega pamiątkowa ku czci Księdza Profesora Remigiusza Popowskiego, s. 22.

42 Usener doskonale znał koncepcje Vica. Wprost wspomina je m.in. w tekście Mythologie, „Archiv für Religionswissenschaft” 1904, Bd. 7, s. 25.

43 „Eripuit coelo fulmen sceptrumque tirannis” - epigram przypisywany Turgotowi; zob. P. Dray, Stealing God's Thunder. Benjamin Franklin's Lighting Rod and the Invention of America, New York 2005, s. 139. 
posłużyć zapanowaniu nad ludzką trwogą ${ }^{44}$. Warto jednak pamiętać, że naukowo-techniczna obietnica zapewnienia człowiekowi bezpieczeństwa stanowi tylko element długotrwałego procesu mierzenia się ludzi z siłami natury, kataklizmami, epidemiami. Ludzki strach był od początku wyzwaniem dla procesu cywilizacji, toteż nazwy, mity i rytuały należy widzieć jako sposoby przeobrażania tego, co obce, w to, co oswojone; tego, co napawa trwogą, w obiekt czci. Język, mit i religia - z punktu widzenia antropologicznego - służyły zarówno orientacji w świecie, jak i redukowaniu naszego lęku przed światem.

\section{Bibliografia}

Michael von Albrecht, „Terror et pavor”: politica e religione in Lucrezio, [w:] „Terror et pavor". Violenza, intimidazione, clandestinità nel mondo antico (Atti del convegno internazionale, Cividale del Friuli, 22-24 settembre 2005), ed. G. Urso, ETS, Pisa 2006.

Aspetti di Hermann Usener filologo della religione, ed. G. Arrighetti [et al.], Giardina, Pisa 1982.

Jan Assmann, Monoteizm jako teologia polityczna, tłum. Ł. Kołoczek, „Znak” 2018, nr 762 (listopad).

Erich Auerbach, Język literacki i jego odbiorcy w późnym antyku łacińskim i średniowieczu, tłum. R. Urbański, Homini, Kraków 2006.

Erich Auerbach, Vico and Aesthetic Historism, „The Journal of Aesthetics and Art Criticism" 1949, Vol. 8, No. 2.

Św. Augustyn, O Państwie Bożym: przeciw poganom ksiąg XXII, t. 1-2, tłum. i oprac. W. Kornatowski, PAX, Warszawa 1977.

Isaiah Berlin, Giambattista Vico i historia kultury, tłum. M. Pietrzak-Merta, [w:] idem, Pokrzywione drzewo człowieczeństwa, tłum. M. Pietrzak-Merda, M. Tański, Prószyński i S-ka, Warszawa 2004.

${ }^{44}$ Dwa lata po wynalazku Franklina Herman Melville w opowiadaniu The Lightning-Rod Man (1854) przedstawił „sprzedawcę gromochronów” jako akwizytora bezpieczeństwa, który używa strachu przed burzą dla osiągnięcia lepszych wyników sprzedaży. Zob. także W. Lepenies, Lęk a nauka, [w:] idem, Niebezpieczne powinowactwa $z$ wyboru. Eseje na temat historii nauki, tłum. A. Zeidler-Janiszewska, Warszawa 1996, s. 32-51. 
Isaiah Berlin, Koncepcja wiedzy u Vica, [w:] idem, Pod prą. Eseje z historii idei, red. H. Hardy, tłum. T. Bieroń, Zysk i S-ka, Poznań 2002.

Remo Bodei, Hermann Usener nella filosofia moderna: tra Dilthey e Cassirer, [w:] Aspetti di Hermann Usener filologo della religione, ed. G. Arrighetti [et al.], Giardini, Pisa 1982.

Jan Maarten Bremer, Zeus' Lightning in Early Greek Myth and in Cleanthes' Hymn, „Roczniki Humanistyczne. 3. Filologia Klasyczna” 2006-2007, t. 54-55: Księga pamiątkowa ku czci Księdza Profesora Remigiusza Popowskiego.

Jan N. Bremmer, Hermann Usener, w: Classical Scholarship. A Biographical Encyclopedia, eds. W.W. Briggs, W.M. Calder III, Garland Publishing, New York - London 1990.

Gianfranco Cantelli, Gestualità e mito: $i$ due caratteri distintivi della lingua originaria secondo Vico, „Bollettino Del Centro di Studi Vichiani” 1990, Vol. 20. Georges Didi-Huberman, The Surviving Image: Aby Warburg and Tylorian Anthropology, „Oxford Art Journal” 2002, Vol. 25, No. 1.

Philip Dray, Stealing God's Thunder. Benjamin Franklin's Lighting Rod and the Invention of America, Random House, New York 2005.

Julien Freund, Le thème de la peur chez Hobbes, „Revue Européenne des Sciences Sociales" 1980, T. 18, No. 49.

Carlo Ginzburg, Strach, Terror i cześć. Co nam mówi Hobbes dziś, tłum. M. Warchala, „Przegląd Polityczny” 2018, nr 147.

Hermann Usener und die Metamorphosen der Philologie, Hrsg. von M. Espagne, P. Rabault-Feuerhahn, Harrassowitz, Wiesbaden 2011.

Fred Hoyle, Katastrofy kosmiczne i narodziny religii, tłum. E. i J. Kaźmierczakowie, WN PWN, Warszawa 1999.

Charles Kahn, Greek Religion and Philosophy in the Sisyphus Fragment, „Phronesis” 1997, Vol. 42, No. 3.

Roland Kany, Hermann Usener as Historian of Religion, „Archiv für Religionsgeschichte" 2004, Bd. 6.

Kartezjusz, Rozprawa o metodzie właściwego kierowania rozumem i poszukiwania prawdy w naukach, tłum. i oprac. W. Wojciechowska, PWN, Warszawa 1970. Johann Kreuzer, Zmysłowość języka, tłum. K. Krzemień-Ojak, „Prace Kulturoznawcze" 2014, t. 16.

Kritias, Syzyf, tłum. J. Gajda, [w:] J. Gajda, Sofiści, Wiedza Powszechna, Warszawa 1989.

Sław Krzemień-Ojak, Vico, Wiedza Powszechna, Warszawa 1971. 
Ewa Kwiatkowska, Vikiański ślad w warburgiańskiej tradycji kulturoznawczej, „Prace Kulturoznawcze” 2014, t. 16.

Joep Leerssen, The rise of Philology: The Comparative Method, the Historicist Turn and the Surreptitious Influence of Giambattista Vico, [w:] The Making of the Humanities II: From Early Modern to Modern Disciplines, eds. R. Bod, J. Maat, T. Weststeijn, Amsterdam University Press, Amsterdam 2012.

Wolf Lepenies, Lęk a nauka, [w:] idem, Niebezpieczne powinowactwa z wyboru. Eseje na temat historii nauki, tłum. A. Zeidler-Janiszewska, Oficyna Naukowa, Warszawa 1996.

Godo Lieberg, The Theologia Tripartita as an Intellectual Model in Antiquity, [w:] Essays in Memory of Karl Kerényi, ed. E.C. Polomé, Institute for the Study of Man, Washington 1984.

Lukrecjusz, O naturze rzeczy, tłum., wstęp i komentarze G. Żurek, PIW, Warszawa 1994.

Frank E. Manuel, U źródeł nowoczesnego religioznawstwa, tłum. M. Król, J. Wiercińska, wstęp H. Hinz, Książka i Wiedza, Warszawa 1973.

Arnaldo Momigliano, Hermann Usener, „History and Theory” 1982, Vol. 21, No. 4. Arnaldo Momigliano, Vico's Scienza Nuova: Roman 'Bestioni' and Roman 'Eroi', „History and Theory” 1966, Vol. 5, No. 1, DOI: 10.2307/2504433.

Na nowo o „Nauce nowej”, red. K. Łukasiewicz, „Prace Kulturoznawcze” 2014, t. 16. Isaac Newton, Philosophiae Naturalis Principia Mathematica, Londini 1687 (wyd. pol. Matematyczne zasady filozofii przyrody, tłum., wstęp i komentarz J. Wawrzycki, Copernicus Center Press - Konsorcjum Akademickie, Kraków - Rzeszów 2011).

Anna Passoni Dell'Acqua, YHWH come dio della tempesta, [w: A Necessary Task Essays on Textual Criticism of the Old Testament in Memory of Stephen Pisano, eds. D. Candido, L. Pessoa da Silva Pinto, GBP, Roma 2020.

Jean Pépin, La „Théologie tripartite” de Varron. Essai de reconstitution et recherche des sources, „Revue des Études Augustiniennes” 1956, Vol. 2.

Jörg Rüpke, Varro's tria genera theologiae: religious thinking in the late Republic, „Ordia Prima” 2005, Vol. 4.

Jürgen Trabant, Vico's New Science of Ancient Signs: A Study of Sematology, Routledge, London - New York 2013.

Traktat o trzech szalbierach [De tribus impostoribus], tłum. T. Włodarczyk, [w:] Filozofowie o religii, wyb., wstęp i przypisy A. Nowicki, Stowarzyszenie Ateistów i Wolnomyślicieli, Warszawa - Kraków 1960. 
Hubert Treiber, For What Purpose do We Still Read the Protestant Ethic Today?, „Società Mutamento Politica” 2014, Vol. 5, No. 9, DOI: 10.13128/SMP-14484. Edward Burnett Tylor, Primitive Culture, London 1871 (wyd. pol. Cywilizacja pierwotna. Badania rozwoju mitologji, filozofi, wiary, mowy, sztuki i zwyczajów, t. 1, tłum Z.A. Kowerska, wstęp i oprac. J. Karłowicz, Wydawnictwo „Głosu”, Warszawa 1896).

Hermann Usener, Götternamen: Versuch einer Lehre von der religiösen Begriffsbildung, F. Cohen, Bonn 1896.

Hermann Usener, Keraunos, Ein Beitrag Religiöser Begriffsgeschichte, „Rheinisches Museum für Philologie” 1905, Bd. 60.

Hermann Usener, Mythologie, „Archiv für Religionswissenschaft” 1904, Bd. 7.

Hermann Usener, Philologie und Geschichtswissenschaft, [w:] idem, Vorträge und Aufsätze, Teubner, Leipzig - Berlin 1907.

Frederick Vaughan, The Political Philosophy of Giambattista Vico: An Introduction to La Scienza Nuova, Springer Netherlands, The Hague 1972.

Giambattista Vico, Nauka nowa, tłum. J. Jakubowicz, oprac. i wstęp S. Krzemień-Ojak, PWN, Warszawa 1966.

Hayden White, Tropika historii: struktura głęboka „Nauki nowej”, [w:] idem, Poetyka pisarstwa historycznego, tłum. E. Domańska, TAiWPN Universitas, Kraków 2000.

Aleksandra Zając, Polityka poetycka Giambattisty Vica, „Politeja” 2017, nr 46. Edward Zwolski, Z historii badań nad religia i mitem. Friedrich Max Müller, czyli dialektyka religii i mitologii, „Roczniki Humanistyczne” 1978, t. 26, z. 2.

\section{Horror of the Sky. Giambattista Vico and Hermann Usener on the Phobic Origins of Culture}

For Giambattista Vico in Principi di una Scienza Nuova (1725), the process of civilization was triggered by a seemingly unimportant event - a thunder strike that filled the primitive people (bestioni) with deadly fear. From that moment, language, religion, the institution of marriage as well as social life emerged. The peculiar hypothesis that the process of civilization was initiated with a crack of thunder found its confirmation in the study by Hermann Usener, titled Keraunos (1905). Almost two centuries after Vico, the German philologist collected evidence that both the Greeks and the Romans worshiped the thunderbolt as a divinity, at first independently 
from Zeus and later as identified with him. Both studies contribute to the understanding of the phobic genesis of culture, and draw attention to the fact that language, art and religion can be considered as different strategies of coming to terms with the horrors of the world.

Keywords: Lucretius, Giambattista Vico, Hermann Usener, Keraunos, thunderbolt, fear, primitivism 